\title{
PROGRAM BIMBINGAN PRIBADI UNTUK MENINGKATKAN PERILAKU DISIPLIN SISWA
}

(PERSONAL GUIDANCE PROGRAM TO IMPROVE STUDENT DICIPLINE BEHAVIOR)

\section{Sri Wahyuni Adiningtiyas.*}

"Division of Counseling and Guidance, University, of Riau Kepulauan, Batam

\begin{abstract}
Abstrak
Program merupakan bahan pertimbangan atau rujukan bagi konselor dalam mengatasi problematika siswa khususnya tentang disiplin. Bimbingan yang dirasakan tepat untuk membantu siswa memiliki disiplin yang baik ialah dengan bimbingan pribadi. Bimbingan pribadi merupakan usaha bimbingan dalam menghadapi dan memecahkan masalah pribadi, seperti penyesuaian diri, menghadapi konflik dan membuat keputusan. Seorang konselor untuk mengambil peran dalam menangani perilaku indisipliner siswa yang terjadi di sekolah. Untuk keperluan tersebut perlu adanya suatu program khusus yang direncanakan secara sistematis, terarah, dan terpadu sebagai upaya mengembangkan kedisiplinan siswa SMA.
\end{abstract}

Kata Kunci: program, bimbingan pribadi, disiplin

\begin{abstract}
The program is a consideration or reference for the counselor in the problem students especially abot the discipline. Guidance that is perceived as appropriate to help students have a good discipline is with personal guidance. Personal guidance is a guidance effort in dealing with and dolving personal problems such as adjustment, confronting conflict and solving personal problems. Counselor to take a role in dealing with students disciplinary behavior occurring in school. For the purpose of the need for a special program that is planned in a systematic, directed and integrated as an effort to develop discipline of high school students.
\end{abstract}

Keyword: program, personal guidance, discipline

\section{Pendahuluan}

Pendidikan merupakan hal yang penting bagi kemajuan dan kelangsungan hidup individu. Individu memperoleh informasi dan pengetahuan yang dapat dipergunakan untuk mengembangkan diri berdasarkan kemampuan dan kesempatan yang ada. Tujuan pendidikan yaitu untuk meningkatkan kecerdasan, pengetahuan, kepribadian, akhlak mulia, keterampilan untuk hidup mandiri serta mengikuti pendidikan lebih lanjut. Pendidikan merupakan peran sentral dalam upaya mengembangkan sumber daya manusia.

Pendidikan di Indonesia dikembangkan berdasarkan pada Undang-undang Sistem Pendidikan Nasional (UUSPN No.20 Th.2003), yang mempunyai tujuan sebagai berikut :

"Pendidikan nasional berfungsi mengembangkan dan membentuk watak serta peradaban bangsa yang bermartabat dalam rangka mencerdaskan kehidupan bangsa, bertujuan untuk berkembangnya potensi peserta didik agar menjadi manusia yang beriman dan bertakwa kepada Tuhan Yang Maha Esa, berakhlak mulia, sehat, berilmu, cakap, kreatif,mandiri, dan menjadi warga negara yan g demokratis serta bertanggung jawab (UUSPN No.20 Th 2003 Bab II Pasal 3)."

Sekolah sebagai lembaga pendidikan formal memiliki tanggung jawab yang besar dalam mengembangkan semua potensi yang dimiliki siswa. Sekolah juga merupakan wahana pendidikan formal yang berperan dalam mengembangkan kualitas manusia Indonesia sejak dini, karena sekolah merupakan tempat dilaksanakannya 
kegiatan pendidikan, pembelajaran dan latihan. Generasi muda pada suatu negara pada dasarnya merupakan salah satu unsur pokok untuk keberlangsungan suatu negara. Kemajuan suatu negara akan sangat dipengaruhi oleh kualitas generasi muda pada negara tersebut.

Siswa SMA sebagai generasi muda berada pada rentang masa remaja yaitu antara usia 13-18 tahun, seperti yang diungkapkan oleh Hurlock (1992: 206) bahwa "awal masa remaja berlangsung kira-kira dari 13 tahun sampai 16 atau 17 tahun, dan akhir masa remaja bermula dari usia 16 atau 17 tahun sampai 18 tahun, yaitu usia matang secara hukum." Umumnya remaja menghabiskan waktu di sekolahnya sekitar 7 jam dalam sehari. Ini artinya bahwa hampir setiap hari, sepertiga waktu mereka digunakan di sekolah. Pengaruh sekolah terhadap perkembangan jiwa remaja cukup besar. Sekolah merupakan lingkungan kondusif untuk mempersiapkan manusia yang memiliki kepribadian dan kedisiplinan yang baik. Kedua hal itu dapat diwujudkan melalui pembinaan pengetahuan, pengenalan sikap, serta nilai-nilai yang berlaku di lingkungan sekolah. Siswa secara psikologis menurut Mulyani (Mohammad Arifana, 2008:1) pada umur 13-18 tahun, perkembangan anak digolongkan sebagai remaja yang mempunyai keinginan baru dan membutuhkan sarana aktivitas yang lebih untuk menumpahkan segala kegiatannya. Dengan minimnya sarana dan prasarana, siswa berpeluang untuk timbulnya permasalahan dalam hal ketertibannya yang dapat berujung pada melanggar aturan-aturan yang ada disekitarnya, maksudnya remaja butuh sarana dan prasarana yang lebih lengkap untuk mengekspresikan diri, jika tidak terpenuhi maka remaja akan berusaha berontak dan mencari apa saja yang bisa digunakan untuk berekspresi. Contohnya, siswa mencorat-coret di dinding WC sekolah atau di dinding kelas, hal itu dilarang oleh sekolah. Hal ini bisa dikurangi jika siswa diberi sarana dan prasarana untuk mengekspresikan diri bisa difasilitasi dengan disediakan tembok khusus untuk mengekspresikan hobi menggambar siswa sehingga itu akan lebih positif. Remaja sebagai seorang siswa dalam mengikuti kegiatan belajar di sekolah tidak lepas dari berbagai peraturan dan tata tertib yang diberlakukan di sekolahnya, dan setiap siswa dituntut untuk dapat berperilaku sesuai dengan aturan dan tata tertib tersebut. Maka remaja harus tunduk dan taat terhadap aturan-aturan yang ada.

Sekolah memiliki tanggung jawab untuk membentuk kedisiplinan siswa. Agar siswa memiliki perilaku disiplin sesuai harapan, sekolah harus memiliki aturan atau norma yang dapat membentuknya. Disiplin sekolah merupakan upaya untuk membentuk perilaku disiplin siswa. Disiplin sekolah diartikan sebagai usaha sekolah untuk memelihara perilaku siswa agar tidak menyimpang dan dapat mendorong siswa untuk berperilaku sesuai dengan norma, peraturan, dan tata tertib yang berlaku di sekolah. Menurut Wikipedia (Akhmad Sudrajat, 2008:1) bahwa disiplin sekolah "refers to students complying $w$ ith a code of behavior often known as the school rules". Yang dimaksud dengan aturan sekolah (school rule) tersebut, seperti aturan tentang standar berpakaian (standards of clothing), ketepatan waktu, 
perilaku sosial dan etika belajar/kerja. Maman Rachman (Akhmad Sudrajat, 2008:1) mengemukakan bahwa tujuan disiplin sekolah adalah: (1) memberi dukungan bagi terciptanya perilaku yang tidak menyimpang, (2) mendorong siswa melakukan yang baik dan benar, (3) membantu siswa memahami dan menyesuaikan diri dengan tuntutan lingkungannya dan menjauhi melakukan hal-hal yang dilarang oleh sekolah, dan (4) siswa belajar hidup dengan kebiasaan-kebiasaan yang baik dan bermanfaat baginya serta lingkungannya.

Sehubungan dengan itu maka setiap individu khususnya siswa membutuhkan kedisiplinan yang tertanam dalam diri, karena dengan disiplin individu dapat menyesuaikan diri dengan lingkungannya secara baik, dapat belajar berperilaku dengan cara yang diterima masyarakat, dan sebagai hasilnya diterima oleh kelompok sosial mereka. Siswa SMA yang memiliki disiplin yang baik akan dapat berperilaku sesuai dengan harapan kelompoknya, mengarahkan siswa untuk hidup menurut standar yang disetujui kelompok sosial sehingga siswa akan memperoleh persetujuan sosial, dan berfungsi sebagai motivasi pendorong ego yang mendorong individu mencapai apa yang diharapkan daripadanya serta membantu individu mengembangkan hati nurani, pembimbing dalam pengambilan keputusan dan pengendalian perilaku (Hurlock, 1990: $82)$.

Disiplin dirasa sangat penting bagi kehidupan dan perilaku siswa, akan tetapi kenyataan di lapangan ditemukan bahwa masih banyak siswa yang tidak peduli dengan pelaksanaan disiplin di sekolahnya. Belakangan ini banyak sekali pelanggaran disiplin yang dilakukan oleh siswa. Bentuk perilaku bermasalah siswa di sekolah ditunjukkan dengan perilaku tidak disiplin. Pada kebanyakan sekolah, siswa memperlihatkan ketidakdisiplinan terhadap tata tertib sekolah. Hal ini dapat dilihat dari banyaknya kasus pelanggaran pada peraturan sekolah yang dilakukan siswa SMA, seperti terlambat datang ke sekolah, bolos pada jam pelajaran, tidak memakai atribut yang lengkap, menggunakan asesoris yang berlebihan dan lain-lain itu sudah hal yang biasa terjadi di sekolah-sekolah.

Jika menyimak pemberitaan di media massa dan elektronik, akhir-akhir ini menggambarkan bahwa tingkat kedisiplinan siswa umumnya masih tergolong memprihatinkan. Kuantitas pelanggaran yang dilakukan oleh siswa semakin bertambah dari waktu ke waktu. Berbagai jenis pelanggaran tata tertib sekolah, misalnya banyaknya siswa yang bolos pada waktu jam belajar, kasus perkelahian yang baru-baru ini sering muncul pemberitaan-pemberitaannya, terlambat datang ke sekolah, sering tidak masuk sekolah, malas belajar, tidak mengerjakan tugas-tugas yang diberikan guru, tidak membuat pekerjaan rumah, merokok, dan lain-lain. (tarmizi.wordpress.com/2008/12/12/kedisiplinan-siswa-di-sekolah/)

Perilaku yang tidak disiplin itu tentunya mempengaruhi siswa dalam kehidupannya sebagai pelajar. Siswa yang tidak disiplin akan selalu bermasalah baik dengan pihak sekolah, wali kelas dan bahkan dengan guru pelajaran. Intinya adalah perilaku tidak disiplin dapat mempengaruhi siswa dalam penyesuaian dirinya dengan tuntutan sekolah. Yang lebih mengkhawatirkan lagi jika perilaku tidak disiplin ini terus 
terjadi dan dibiarkan maka akan mempengaruhi siswa dalam upaya penyesuaian dirinya dengan masyarakat.

Salah satu cara yang dapat dilakukan oleh pihak sekolah dalam membantu siswa untuk meningkatkan disiplin di sekolah yaitu dengan merumuskan dan melaksanakan program bimbingan pribadi. Program merupakan bahan pertimbangan atau rujukan bagi konselor atau guru pembimbing dalam mengatasi problematika siswa khususnya tentang disiplin. Bimbingan yang dirasakan tepat untuk membantu siswa memiliki disiplin yang baik ialah dengan bimbingan pribadi. Bimbingan pribadi ini lebih diarahkan untuk memantapkan kepribadian dan mengembangkan kemampuan individu dalam menangani masalah-masalah dirinya. Sukardi (1993) mengungkapkan bahwa bimbingan pribadi merupakan usaha bimbingan dalam menghadapi dan memecahkan masalah pribadi, seperti penyesuaian diri, menghadapi konflik dan membuat keputusan.

Oleh karena itu, maka sudah menjadi tugas seorang konselor untuk mengambil peran dalam menangani perilaku indisipliner siswa yang terjadi di sekolah. Untuk keperluan tersebut perlu adanya suatu program khusus yang direncanakan secara sistematis, terarah, dan terpadu sebagai upaya mengembangkan kedisiplinan siswa SMA.

Berdasarkan paparan di atas, maka perlu suatu pengkajian mendalam tentang:

\section{"Program Bimbingan Pribadi untuk Meningkatkan Perilaku Disiplin Siswa".}

\section{Pembahasan}

\section{a. Disiplin}

Disiplin bagi peserta didik adalah hal yang rumit dipelajari sebab merupakan hal yang kompleks dan banyak kaitannya, yaitu terkait dengan pengetahuan, sikap dan perilaku. Masalah disiplin yang dibahas dalam penelitian ini adalah disiplin yang dilakukan oleh para siswa dalam kegiatan belajarnya baik di rumah maupun di sekolah. Untuk lebih memahami tentang disiplin belajar terlebih dahulu akan dikemukakan pengertian disiplin menurut beberapa ahli.

1. Menurut Ekosiswoyo dan Rachman (2000), disiplin hakikatnya adalah pernyataan sikap mental individu maupun masyarakat yang mencerminkan rasa ketaatan, kepatuhan, yang didukung oleh kesadaran untuk menunaikan tugas dan kewajiban dalam rangka pencapaian tujuan.

2. Menurut Arikunto (1990), di dalam pembicaraan disiplin dikenal dua istilah yang pengertiannya hampir sama tetapi pembentukannya secara berurutan. Kedua istilah itu adalah disiplin dan ketertiban, ada juga yang menggunakan istilah siasat dan ketertiban. Ketertiban menunjuk pada kepatuhan seseorang dalam mengikuti peraturan dan tata tertib karena didorong oleh sesuatu dari luar misalnya karena ingin mendapat pujian dari atasan. Selanjutnya pengertian disiplin atau siasat menunjuk pada kepatuhan seseorang dalam mengikuti tata tertib karena didorong kesadaran yang ada pada kata hatinya. Itulah sebabnya biasanya ketertiban itu terjadi dahulu, kemudian berkembang menjadi siasat. 
3. Menurut Lembaga Ketahanan Nasional (Lemhannas,1997), makna kata disiplin dapat dipahami dalam kaitannya dengan latihan yang memperkuat, koreksi dan sanksi, kendali atau terciptanya ketertiban dan keteraturan dan sistem aturan tata laku.

Berdasarkan berbagai macam pendapat tentang definisi disiplin diatas, dapat diketahui bahwa disiplin merupakan suatu sikap moral siswa yang terbentuk melalui proses dari serangkaian perilaku yang menunjukkan nilai-nilai ketaatan, kepatuhan, keteraturan dan ketertiban berdasarkan acuan nilai moral. Berdisiplin sangat penting bagi setiap siswa. Berdisiplin akan membuat seorang siswa memiliki kecakapan mengenai cara belajar yang baik, juga merupakan suatu proses ke arah pembentukan watak yang baik.

Fungsi disiplin menurut Tulus Tu'u (2004) adalah:

\section{Menata kehidupan bersama}

Disiplin berguna untuk menyadarkan seseorang bahwa dirinya perlu menghargai orang lain dengan cara menaati dan mematuhi peraturan yang berlaku, sehingga tidak akan merugikan pihak lain dan hubungan dengan sesama menjadi baik dan lancar.

2. Membangun kepribadian

Pertumbuhan kepribadian seseorang biasanya dipengaruhi oleh faktor lingkungan. Disiplin yang diterapkan di masing-masing lingkungan tersebut memberi dampak bagi pertumbuhan kepribadian yang baik. Oleh karena itu, dengan disiplin seseorang akan terbiasa mengikuti, mematuhi aturan yang berlaku dan kebiasaan itu lama kelamaan masuk ke dalam dirinya serta berperan dalam membangun kepribadian yang baik.

\section{Melatih kepribadian}

Sikap, perilaku dan pola kehidupan yang baik dan berdisiplin terbentuk melalui latihan. Demikian juga dengan kepribadian yang tertib, teratur dan patuh perlu dibiasakan dan dilatih.

\section{Pemaksaan}

Disiplin dapat terjadi karena adanya penaksaan dan tekanan dari luar, misalnya ketika seorang siswa yang kurang disiplin masuk ke satu sekolah yang berdisiplin baik, terpaksa harus mematuhi tata tertib yang ada di sekolah tersebut.

\section{Hukuman}

Tata tertib biasanya berisi hal-hal positif dan sanksi atau hukuman bagi yang melanggar tata tertib tersebut.

\section{Menciptakan lingkungan yang kondusif}

Disiplin sekolah berfungsi mendukung terlaksananya proses dan kegiatan pendidikan agar berjalan lancar dan memberi pengaruh bagi terciptanya sekolah sebagai lingkungan pendidikan yang kondusif bagi kegiatan pembelajaran. 
Terdapat beberapa faktor atau sumber yang dapat menyebabkan timbulnya masalah-masalah yang dapat mengganggu terpeliharanya disiplin. Menurut Ekosiswoyo dan Rachman (2000), contoh-contoh sumber pelanggaran disiplin antara lain:

Dari sekolah, contohnya:

1. Tipe kepemimpinan guru atau sekolah yang otoriter yang senantiasa mendiktekan kehendaknya tanpa memperhatikan kedaulatan siswa. Perbuatan seperti itu mengakibatkan siswa menjadi berpura-pura patuh, apatis atau sebaliknya. Hal itu akan menjadikan siswa agresif, yaitu ingin berontak terhadap kekangan dan perlakuan yang tidak manusiawi yang mereka terima.

2. Guru yang membiarkan siswa berbuat salah, lebih mementingkan mata pelajaran daripada siswanya.

3. Lingkungan sekolah seperti: hari-hari pertama dan hari-hari akhir sekolah (akan libur atau sesudah libur), pergantian pelajaran, pergantian guru, jadwal yang kaku atau jadwal aktivitas sekolah yang kurang cermat, suasana yang gaduh, dll

Dari keluarga, contohnya:

1. Lingkungan rumah atau keluarga, seperti kurang perhatian, ketidak teraturan, pertengkaran, masa bodoh, tekanan, dan sibuk urusannya masing-masing.

2. Lingkungan atau situasi tempat tinggal, seperti lingkungan kriminal, lingkungan bising, dan lingkungan minuman keras.

Sulistyowati (2001) menyebutkan agar seorang pelajar dapat belajar dengan baik ia harus bersikap disiplin, terutama disiplin dalam hal-hal sebagai berikut:

1. Disiplin dalam menepati jadwal belajar.

2. Disiplin dalam mengatasi semua godaan yang akan menunda-nunda waktu belajar.

3. Disiplin terhadap diri sendiri untuk dapat menumbuhkan kemauan dan semangat belajar baik di sekolah seperti menaati tata tertib, maupun disiplin di rumah seperti teratur dalam belajar.

4. Disiplin dalam menjaga kondisi fisik agar selalu sehat dan fit dengan cara makan yang teratur dan bergizi serta berolahraga secara teratur.

\section{Faktor yang Mempengaruhi Disiplin}

Disiplin turut berpengaruh terhadap hasil belajar. Hal ini dapat terlihat pada siswa yang memiliki disiplin yang tinggi akan belajar dengan baik dan teratur dan akan menghasilkan prsetasi yang baik pula. Demikian sebaliknya faktor-faktor belajar turut berpengaruh terhadap tingkat disiplin individu. Hal ini dapat dilihat dari penjelasan faktor-faktor yang mempengaruhi belajar, yaitu sebagai berikut :

1) Faktor yang berasal dari luar diri siswa

Faktor dari luar dibagi menjadi dua bagian yaitu :

a. Faktor non-sosial, seperti keadaan uadara, suhu udara, waktu, tempat dan alat-alat yang dipakai untuk belajar. Siswa yang memiliki tempat belajar yang teratur dan memiliki buku penunjang pelajaran cenderung lebih disiplin dalam belajar. Tidak 
kalah pentingnya faktor waktu, siswa yang mampu mengatur waktu dengan baik akan belajar secara terarah dan teratur.

b. Faktor soial, terdiri atas lingkungan keluarga, lingkungan sekolah, lingkungan masyarakat dan lingkungan kelompok. Siswa yang tinggal dalam lingkungan yang tertib tentunya siswa tersebut akan menjalani tata tertib yang ada di lingkungannya. Seorang guru yang mendidik siswa dengan disiplin akan cenderung menghasilkan siswa yang disiplin pula.

2) Faktor yang berasal dari dalam diri siswa faktor yang berasal dari dalam diri siswa dibagi menjadi dua yaitu

a. Faktor fisiologis, yang termasuk dalam faktor fisiologis antara lain, pendengaran, penglihatan, kesegaran jani, keletihan, kekurangan gizi, kurang tidur dan sakit yang di derita. Faktor fisiologis ikut berperan dalam menentukan disiplin blajar siswa. Siswa yang tidak menderita sakit cenderung lebih disiplin dibandingkan siswa yang menderita sakit dan bdannya keletihan.

b. Faktor Psikologis, Faktor psikologis yang dapat mempengaruhi proses belajar antara lain:

(1) Minat

Minat sangat besar pengaruhnya terhadap prsetasi belajar. Seseorang yang tinggi minatnya dalam mempelajari sesuatu akan dapat meraih hasil yang tinggi pula. Apabila siswa memiliki minat yang tinggi terhadap pelajaran akan cenderung disiplin dalam belajar.

(2) Bakat

Bakat merupakan faktor yang besar peranannya dalam proses belajar. Mempelajari sesuatu sesuai dengan bakatnya akan memperoleh hasil yang lebih baik.

(3) Motivasi

Motivasi merupakan kondisi psikologis yang mendorong seseorang untuk melakukan sesuatu. Fungsi motivasi dalam belajar adalah untuk memberikan semangat pada seseorang daam belajar untuk mencapai tujuan.

(4) Konsentrasi

Konsentrasi dapat diartikan sebagai suatu pemusatan energi psikis yang dilakukan untuk suatu kegiatan tertentu secara sadar terhadap suatu obyek (materi pelajaran).

(5) Kemampuan kognitif

Tujuan belajar mencakup tiga aspek yaitu kognitif, afektif dan psikomotor. Namun kemampuan kognitif lebih diutamakan, sehingga dalam menacapai hasil belajar faktor kemampuan kognitif lebih diutamakan.

Faktor eksternal dan internal tersebut memiliki peranan yang sangat penting dan sangat diperlukan daklam belajar. Untuk mencapai hasil yang optimal dalam proses belajar, maka dituntut adanya keseimbangan di antara keduanya. Jika salah satu factor tersebut ada kekurangan akan berpengaruh pada hasil belajar yang dicapai. 


\section{Upaya Guru BK dalam Mengembangkan Disiplin Belajar Siswa}

Guru sebagai pendidik mempunyai peranan penting dalam mengembangkan disiplin diri siswa. Pada saat proses pembelajran berlangsung, para guru dituntut untuk dapat melakukan kontrol ekstemal dengan melakukan tindakan-tindakan yang dapat membentuk"self disciplineft siswa, sehingga diharapkan siswa dapat mentaati peraturan, norma dan batasan-batasan perilaku dirinya. Upay untuk mengembangkan disiplin diri adalah melalui penanman dsiplin. Dengan penanaman disiplin ini guru berusaha menciptakan situasi proses belajar mengajar yang dapat mendorong siswa untuk berdisiplin diri dalam belajamya.

Pengembangan disiplin oleh guru cenderung dilakukan di dalam kelas, oleh karena itu selanjutnya timbul pertanyaan: Kelas yang bagaimana yang dikatakan disiplin? Untuk mejawab pertanyaan ini kita dapat menyimak apa yang dikatakan William Gnagey bahwa:

Good discipline refers to a situation in which your students are exerting an optimal amount of energy trying to learn what you want to teach them instead of wasting it in various other counter productive activities (Gnagey, 1981).

Pemyataan di atas memperlihatkan bahwa displin akan terbentuk apabila setiap siswa memiliki motivasi yang kuat untuk melibatakan diri secara aktif dalam proses pembelajaran. Dengan perkataan lain, tanpa partisipasi siswa (melalui motivasi yang kuat), apapun yang diupayakan guru dalammengembangkan disiplin belajar tidak akan berhasil secara optimal.

Dalam rangka mengembangkan disiplin diri siswa dalam belajar, Yusuf (1989) menegemukakan ada beberapa hal yang perlu menjadi perhatian guru yaitu sebagai berikut:

1. Guru hendaknya menjadi model bagi siswa Guru hendaknya berperilaku yang mencerminkan nilai-nilai moral, sehingga ia menjadi figure sentral bagi siswa dalam menerjemahkan nilai-nilai tersebut dalam perilakunya, seperti bel1aku jujur, berdisiplin dalam melaksanakan tugas, rajin belajar dan bersikap optimis dalam menghadapi persoalan hidup.

2. Guru hendaknya memahami dan menghargai pribadi siswa

3. Guru memberikan bimbingan kepada siswa

a. Mengembangkan yang bebas dari dan yang membantu siswa iklim kelas ketegangan bersuasana perkembangan

b. Memberikan informasi tentang cara-cara beljar yang efektif

c. Mengadakan dialog tentang tujuan dan manfaat peraturan belajar yang ditetapkan sekolah (guru) dengan siswa

d. Membantu siswa untuk mengembangkan kebiasaan belajar yang baik

e. Membantu mengembangkan sikap positif siswa terhadap belajar

f. Membantu siswa yang mengalami masalah, terutama masalah belajar dan

g. Memberikan informasi tentang nilai-nilai yang bellaku, dan mendorong siswa agar berperilaku sesuai dengan nilai-nilai tersebut. 


\section{Penutup}

Membicarakan tentang disiplin sekolah tidak bisa dilepaskan dengan persoalan perilaku negatif siswa. Perilaku negatif yang terjadi di kalangan siswa remaja pada akhir-akhir ini tampaknya sudah sangat mengkhawarirkan, seperti: kehidupan sex bebas, keterlibatan dalam narkoba, gang motor dan berbagai tindakan yang menjurus ke arah kriminal lainnya, yang tidak hanya dapat merugikan diri sendiri, tetapi juga merugikan masyarakat umum. Di lingkungan internal sekolah pun pelanggaran terhadap berbagai aturan dan tata tertib sekolah masih sering ditemukan yang merentang dari pelanggaran tingkat ringan sampai dengan pelanggaran tingkat tinggi, seperti: kasus bolos, perkelahian, nyontek, pemalakan, pencurian dan bentuk-bentuk penyimpangan perilaku lainnya. Tentu saja, semua itu membutuhkan upaya pencegahan dan penanggulanggan dari berbagai pihak khususnya guru BK dalam membuat program dalam meningkatkan disiplin siswa.

\section{Kesimpulan}

Seorang siswa dalam mengikuti kegiatan belajar di sekolah tidak akan lepas dari berbagai peraturan dan tata tertib yang diberlakukan di sekolahnya, dan setiap siswa dituntut untuk dapat berperilaku sesuai dengan aturan dan tata tertib yang yang berlaku di sekolahnya. Tujuan disiplin sekolah adalah : (1) memberi dukungan bagi terciptanya perilaku yang tidak menyimpang, (2) mendorong siswa melakukan yang baik dan benar, (3) membantu siswa memahami dan menyesuaikan diri dengan tuntutan lingkungannya dan menjauhi melakukan hal-hal yang dilarang oleh sekolah, dan (4) siswa belajar hidup dengan kebiasaan-kebiasaan yang baik dan bermanfaat baginya serta lingkungannya. Di dalam kelas, jika seorang guru tidak mampu menerapkan disiplin dengan baik maka siswa mungkin menjadi kurang termotivasi dan memperoleh penekanan tertentu, dan suasana belajar menjadi kurang kondusif untuk mencapai prestasi belajar siswa.

\section{DAFTAR PUSTAKA}

Akhmad Sudrajat. 2008. Pengertian Pendekatan, Strategi, Metode, Teknik dan Metode, Teknik dan Model Pembelajaran. Bandung: Sinar Baru Algensindo.

Ekosowoyo dan Rachman. 2000. Manajemen Kelas. Semarang: IKIP.

Hurlock, E.B. 1992. Psikologi Perkembangan: Suatu Pendekatan Sepanjang Rentang Kehidupan. Jakarta: Erlangga.

Lemhanas. 1997. Jakarta

Mohammad Arifana. 2008. Psikologi Remaja. Jakarta: PT Bumi Aksara.

Rachman. 1999. Strategi dan Langkah Penelitian. Semarang: IKIP.

Sukardi. 1993. Bimbingan Karir di Sekolah. Jakarta: Balai Pustaka.

Tulus Tu'u. 2004. Peran Disiplin pada Perilaku dan Prestasi Siswa. Jakarta: Qrasindo. 